\title{
Canada's Visa Requirement For Mexicans and Its Political Rationalities
}

\author{
Liette GILBERT*
}

\begin{abstract}
In July 2009, the Harper government imposed a visa requirement on all Mexicans traveling to Canada. The Canadian government legitimized its decision by alluding to the rising number of requests for refugee status from Mexico. This article examines the official rhetoric used by Conservative politicians to rationalize this requirement and immigration and refugee law reform. I argue that the imposition of the visa intended to stop refugee claimants from Mexico also serves to criminalize them using official rhetoric and prejudicial language. That discourse implies the bilateral denial of the human rights crisis created by narco-violence and corruption.
\end{abstract}

Key words: visa requirement, Mexicans, refugee policy, fraud, abuse, prejudice, violence.

\section{RESUMEN}

En julio de 2009, el gobierno de Harper impuso un requisito de visa para todos los mexicanos que viajen a Canadá. El gobierno canadiense legitimó esta decisión tomando como pretexto el número creciente de solicitudes de asilo provenientes de mexicanos. Este artículo examina la retórica usada por los políticos conservadores para justificar el requisito exigido a los mexicanos y las leyes de reforma a la inmigración y de refugiados. Aquí se sostiene que la imposición de la visa intenta detener el número de solicitantes de asilo que provienen de México, a la vez que los criminaliza utilizando una retórica oficial y un lenguaje prejuicioso. Este discurso implica la negación bilateral de la crisis de derechos humanos creada por la narcoviolencia y la corrupción. Palabras clave: requisito de visa, mexicanos, política de refugio, fraude, abuso, prejuicio, violencia.

\footnotetext{
* Associate professor, Faculty of Environmental Studies, York University, Toronto. gilbertl@yorku.ca.
} 


\section{INTRODUCTION}

The signing of the North American Free Trade Agreement (NAFTA) 15 years ago resolved to "strengthen the special bonds of friendship and cooperation among" the governments of Canada, Mexico, and the United States (NAFTA Secretariat, 1993). Canada's decision to impose a visa requirement on Mexicans therefore appears as a peculiar quinceañera gift offered to a so-called amigo and strategic economic partner. The visa initiative was announced on July 13, 2009, to go into effect the very next day, surprising many and stirring up media attention and diplomatic relations. Canada's Minister of Citizenship, Immigration and Multiculturalism Jason Kenney's rationale was that the visa requirement gave the Canadian government "greater ability to manage the flow of people into Canada and verify bona fides. By taking this important step towards reducing the burden on our refugee system, we [Canada] will be better equipped to process genuine refugee claims faster" (Citizenship and Immigration Canada, 2009a). ${ }^{1}$

Mexico has been the leading country presenting refugee claims since 2005. In 2008, Canada received 9322 refugee claims submitted by Mexicans, the highest number from Mexico in history (Citizenship and Immigration Canada, 2012). The Canadian government legitimized its decision to impose a visa condition on Mexicans based on the rising number of refugee claims in recent years. ${ }^{2}$ This new requirement meant that all Mexicans who wanted to visit Canada would first need to apply for a temporary resident visa. The visa requires a person not overstay their time in Canada, have enough money to cover their stay, be in good health, have no criminal record, and not be considered a security risk to Canadians (Citizenship and Immigration Canada, 2009b). Applicants had to travel to Mexico City -visa application centers have since opened in Monterrey and Guadalajara- with a panoply of specific documentation, including a passport, a letter from employer(s) granting a leave of absence (in English or French), recent pay slips, original bank documents showing financial history from the previous six months, evidence of assets in Mexico, and invitations where applicable (Canada Visa Application Centre, 2011). For many applicants, the required documentation has been excessively onerous or simply impossible to assemble. The visa requirement broadly cast its goal as the deterrence of travel to Canada (Ramírez Meda and Biderbost Moyano, 2011). ${ }^{3}$

\footnotetext{
${ }^{1}$ In a separate press release on the same day, a visa requirement was also imposed on travellers from the Czech Republic to deter Roma refugee claimants.

${ }^{2}$ Mexico appeared among Canada's top 10 countries for refugee claims in 1996 when it ranked ninth, with 946 applications. In 2000, it ranked seventh, with 1317 applications, and first in 2005 with 3 550. In 2010, a year after the visa requirement was imposed, it ranked fourth, with 1299 applications (Citizenship and Immigration Canada, 2012).

${ }^{3}$ Canada's documentation required to apply for a temporary resident visa is more onerous and stricter than
} 
This article seeks to unpack the official rhetoric used by Conservative politicians to justify the visa requirement for Mexicans and its implications. Mexican refugee claimants have been perceived as a problem in Canada because the Conservative government has increasingly claimed that "real" refugees are those waiting destitute in camps overseas. The growing number of Mexican refugee claimants does not fit this profile, and therefore they are assumed by Canadian authorities to be fraudulently trying to come to Canada to take advantage of the refugee and welfare system. The visa requirement was therefore imposed as a control and deterrence mechanism in this dual context of presumed "fraud" and "abuse." These presumptions constructed Mexican nationals as a "threat" to Canada's national borders and welfare system and, in doing so, rendered refugee claimants undesirable and ungovernable. Such presumptions therefore rationalize the visa requirement in Mexico as well as a larger reform to the refugee determination process in Canada. As part of a larger restrictive policy regime to control people from particular states, the visa measure also criminalizes refugee claimants (on an individual and collective/national basis), and erodes human rights in refugee politics by denying the human rights crisis created by narco-violence and corruption in Mexico. Moreover, the undifferentiated construction of all Mexicans, whether refugee claimants or visitors, as a "threat" to Canada's immigration and refugee system, social welfare, and national borders conveniently disregards the dominant economic discourse of Mexico as a close political friend and strategic trading partner, the latter view underpinning the perception of Mexico as a "safe country." It is anticipated that the designation of Mexico as a "safe country" by Minister Kenney as part of Canada's refugee and immigration reform will end the visa requirement by affirming that Mexico does not produce refugee claimants, even though violence keeps pushing people out.

After a brief summary of the range of reactions to the visa requirement in Canada and Mexico, I contextualize border controls in the larger tension between migration and the globalized economy, and the constitutive discourse of the "illegality" attributed to Mexican migrants in North America. I then examine the particular criminalization of Mexican refugee claimants through the construction of their claims as "fraudulent" in the official public discourse. I discuss how Conservative politicians' prejudicial official language blaming refugee applicants has been used to justify the visa requirement in Mexico and the reform of the refugee determination system in Canada. The last section looks at how the current narco-violence in Mexico poses a particular challenge to the definition of "refugee" and Canada's designation of Mexico

that for a non-immigrant visa for the United States. The U.S. visitor visa requires a valid passport, fee payment, travel information, and evidence of funds to cover expenses (United States Department of State, 2012). 
as a "safe country" in the context of its ongoing immigration and refugee reform. My argument is that the normalization of the Mexican refugee claimants as "fraudulent claimants" and "system abusers" in Canada's public discourse was used to rationalize and normalize the need for the visa requirement. Moreover, the designation of Mexico as a "safe country" is based on a complementary political rationality that Mexicans are in no need of protection despite Mexico's narco-violence and human rights abuse by the state.

\section{Visa Rationalization and Reactions}

Canada's visa requirement for Mexican travellers was a severe blow to fragile continental trilateralism, and more specifically to the "aspirations of Canada-Mexico strategic partnership" (Studer Noguez, 2009). The visa prerequisite significantly challenged the myth of seamless continental integration and accentuated the asymmetrical relationships among NAFTA partners. Until now, Mexico saw Canada as the more reasonable, though less important, NAFTA partner. Bilateral Mexican-U.S. trade relations have been very successful but constantly strained by immigration issues specifically related to cross-border mobility and the significant "unauthorized" Mexican population living north of the border. Canada's sudden visa requirement for Mexicans generated a similar anxiety about Canadian border governance politics, now extended from the border itself into the visa offices in Mexico. Literally overnight, the image of Canada in Mexico shifted from that of an open to an exclusionary society.

The announcement of the visa requirement took many people in Canada and in Mexico by surprise -not least the Canadian embassy in Mexico City, who were informed of it only a few days before it was put in place (anonymous, 2009). Prime Minister Stephen Harper had apparently discussed this possibility with the Calderón administration in November 2008 (Studer Noguez, 2009). Reactions from the Mexican government, although numerous in the media, were restrained. The requirement was perceived as an "irritant" in the relations between NAFTA partners and even as a "slap in the face" from a supposedly friendly country (Simpson, 2010: F9). Many Mexican commentators considered the sudden visa provision as more detrimental to the majority of legitimate Mexican travellers to Canada than to the smaller portion of alleged "illegitimate" refugee claimants (Ramírez Meda and Biderbost Moyano, 2011; Ross, 2010: A14).

Mexican Foreign Affairs Minister Patricia Espinosa officially expressed disagreement with the measure, but Mexican legislators stopped short of asking for reciprocal visa restrictions given the importance of Canadian tourism for the Mexican economy 
(Latin America Data Base, 2009; Ramírez Meda and Biderbost Moyano, 2011; Hernández, 2009). In the days following the announcement, Mexico partially reciprocated the visa imposition for the small group of Canadians carrying diplomatic and official passports (Ramírez Meda and Biderost Moyano, 2011). Ottawa disregarded a request from Mexico's Foreign Relations Ministry for a 45-day delay in the implementation of the visa requirement (Latin America Data Base, 2009). The official Mexican government response was to characterize the decision as regrettable and to continue to promote actions toward modifying it (Mexican Embassy in Canada quoted in O'Neil and Fitzpatrick, 2009). President Felipe Calderón's reaction was rather subdued in the face of the dispute, stating, "We deeply respect Canada's right to make decisions about its immigration system. However, I must share with you our regret for this series of events and decisions" (Valpy, 2009: A13). His muted regret was accompanied by an acknowledgement of the surge in "illegitimate" refugee claims created by the operations of dubious "intermediary groups and organizations" (i.e., polleros de cuello blanco, or white-collar people smugglers) in Mexico exploiting Canada's slow-moving refugee determination process (Valpy, 2009; Martínez, 2009). Canadian Foreign Affairs Minister Lawrence Cannon faced the discontent of Mexican officials and business organizations that saw the new measure as running counter to integration efforts in the North American continent. In an attempt to prevent further diplomatic damage, Cannon initially suggested that the action would be temporary but was nevertheless necessary, given that the number of refugee claims from Mexico "has been above the level that is acceptable" (Latin America Data Base, 2009). Calderón, in subsequent official visits, reiterated his hopes that the measure would indeed be temporary, lasting until Canada reforms its immigration and refugee law, something obviously beyond his control.

In Canada, reactions against what has been described as "one of the most perplexing and possibly damaging foreign policy decisions" (Collins, 2009a) appear more vociferous. The Liberal immigration critic Maurizio Bevilacqua and the NDP immigration critic Olivia Chow argued that a blanket visa requirement on the entire population of a country amounted to nothing less than a damning indictment of the Conservatives' inefficient governing of the refugee determination system (Collins, 2009a). Liberal foreign affairs critic Bob Rae denounced the visa imposition as a "big step backward" for bilateral relations (quoted in Davis, 2009a). In an open letter to the federal Conservative government, Quebec's Liberal government criticized the new regulation, denounced its negative effects on trade and tourism, and dubbed the regulation an affront to a NAFTA partner (Gouvernement du Québec, 2009). In an open letter to Mexican officials, Canadian Senator Céline Hervieux-Payette (2009), writing "on behalf of Canadians who do not support their government's extreme-right policies," apologized for the "unacceptable" decision and explained that Canada's Conservative 
government, ever since its election in 2006, has undermined Canada's reputation abroad with "its extreme-right ideology, its partisan, campaign-style decisions, and demagoguery."

Non-governmental organizations such as the Canadian Council for Refugees (2009a) also condemned the closing of the door on refugees from Mexico as an unfair attempt to undermine the legitimacy of claimants. The United Nations High Commissioner for Refugees, via his top representative in Canada, also expressed serious concerns about the use of a visa to reduce refugee claims and insisted on Canada's duty and responsibility to listen to individual claims in order to determine refugee status (quoted in Davis, 2009b). Amnesty International (2009) also denounced the use of the visa requirement for Mexico as a tool to explicitly restrict access to refugee determination procedures, while reminding Conservative politicians that it was not their personal prerogative, but rather the role of the Immigration and Refugee Board of Canada, to determine eligibility.

Less than one month after the visa announcement, Harper participated in the annual North American Leaders' Summit in Guadalajara, the so-called "Three Amigos Summit," and justified the imposition of a visa on the basis of the rise in "bogus claims" from Mexicans. Harper (quoted in Mayeda, 2009) stated,

We are spending an enormous amount of money on bogus refugee claims.... This is not the fault of the government of Mexico. Let me be very clear about this. This is a problem with Canadian refugee law, which encourages bogus claims. ... I hope our Parliament will take advantage of the attention that's been brought on this issue to deal with this problem.

In shifting the "fault" to the need for Canadian refugee law reform, the statement reads as a poor attempt to assuage stressed diplomatic relations between Canada and Mexico. Contrary to Mexican expectations, Harper could not offer any assurance to Mexico's President Felipe Calderón that Ottawa's visa requirement would be lifted anytime soon, but defensively stated that it would no longer be necessary once Canada made changes to its refugee system (quoted in Whittington, 2009). Still, Harper clearly saw the claims and claimants as illegitimate, covering his view by discharging the Mexico government of any responsibility and blaming Canadian refugee law for its operational inefficiencies. The prime minister reiterated the need for the visa requirement during President Calderón's official visit to Ottawa in May 2010, at the exact same time that Bill C-11: The Balanced Refugee Reform Act was being vigorously discussed in the House of Commons Standing Committee on Citizenship and Immigration. The contested act imposed shorter timelines for a list of designated countries of origin, and received royal assent in June 2012. Harper strictly repeated his dogmatic rationale of 
the visa as "our sole method of control when we face a torrent of bogus applications" (quoted in Campion-Smith, 2010: 14). The Harper government never entertained alternatives offered by the Mexican government to enhance screening of Mexican travellers to Canada or to crack down on the lucrative business of deceitful immigration brokers who encourage Mexicans to seek asylum in Canada. Harper and Kenney have publicly condemned the alleged "bogus" refugee claimants without any attempt to situate the phenomenon within the larger political economic context of Mexico's drug war and economy. The Mexican government's unhappiness about the visa measure and lack of power to change the situation hide a complicit silence about Mexico's structural problems, violence and corruption (Hernández Velázquez, Leco Tomás, and Aguilar Armendáriz, 2011; Estévez, 2012a; Wright, 2012).

\section{The Changing North American Immigration Landscape}

The globalized economy has generated an unprecedented pool of migrants by favoring the internationalization of labor, yet unevenly enabling cross-border mobility. National immigration policies have responded in various ways, many of them favoring highly skilled workers while increasingly relegating low-skilled migrants to temporary worker programs and informal economies. For some, moving across borders has become a condition of their cosmopolitan lives and professional activities, expedited by the convenience of border pre-clearance registration programs. However, for others, moving across borders represents, more than ever, a perilous journey through tighter border controls toward informal and precarious work conditions. According to 2009 United Nations population estimates, 213 million migrants were on the move worldwide in 2010. Of this number, 16 million were refugees i.e., people seeking protection in another country. Dauvergne (2008) estimates that, in 2005, 50 million people worldwide were caught in a state of "extra-legality" created by the contradictions of economic globalization, state sovereignty, and human rights. These are migrants who do not fit any categories of national immigration laws or international refugee agreements and yet are a growing part of the globalized work force (Dauvergne, 2008; Bacon, 2008; Massey, Durand, and Malone, 2002).

Still, people moving outside national legal frameworks or contravening immigration laws are quickly labeled "illegal." Illegality is associated with anyone entering a country in breach of immigration law or overstaying permitted stays in a country. Yet, as Dauvergne (2008: 16) argues, the term illegality "underscores a shift in perception regarding the moral worthiness of migrants" and creates a moral and national superiority for those perceiving immigration infringements as criminal activity. The 
labeling of "illegals" has allowed governments, media, and neoconservative groups to reassert rhetorical and moral borders over migrants when official borders remain somewhat porous because of constant labor demands. This perceived criminality is directly linked to migrants' unauthorized presence in a country and their assumed disregard for the "legal immigration" process and queue. But as Carens remarks (2010: 42), “There are almost no immigration lines for unskilled workers without close family ties to current citizens or residents. Most of those who settle as irregular migrants would have no possibility of getting in through any authorized channel. To say that they should stand in a line which does not exist or does not move is disingenuous." As a result of the contentious relation between the unremitting flows of globalization and the intensified securitization of national borders by sovereign states, immigration and refugee laws have increasingly become the determination of those who must be turned away rather than those who are allowed to enter. Thus, migrants' mobility has been severely curtailed by various governmental technologies, whether visas or any other punitive legislation.

In the face of political rationalities and a regime of rules preoccupied with economic efficiency, national security and safety, and social order based on exclusion, "illegality" emerges as the direct outcome of immigration law (Dauvergne, 2008; Newton, 2008; De Genova, 2004; Bigo, 2002). As De Genova (2004) demonstrates, the historical interplay between unlimited demands for Mexican labor and the rendering of Mexican labor as distinctly disposable in U.S. immigration law instituted the legal production of Mexican/migrant illegality. In recent years, many governments (the U.S., Canada, and Australia, among others) have created new immigrant-related crimes, increasing penalties and prosecutions at the border and the workplace, expanding the grounds for being outside the law and therefore expanding the grounds for illegality (Kanstroom, 2004; Dauvergne, 2008). Migrants are thus rendered "illegals" by a normalized criminalizing process in immigration laws, public discourses, and neoconservative politics, and, as Robert Latham (2009) concludes, any solution to border mobility must be framed outside the criminalizing laws but as a challenge to those specific laws.

This convergence of economic globalization and national security has created difficult conditions for many international migrants. Unable to live in their home countries due to political and economic uncertainties, they are unable to migrate within the increasingly restrictive national immigration and refugee regimes. Over the years, the reaction of extreme-right conservative governments has been to decry and further restrict the entrance of migrants via public policies and xenophobic rhetoric. In recent years, mimicking the restrictive immigration agenda debated and adopted in the United States since the late 1990s and particularly since 2001, Canada has stepped up migration and security enforcement by restricting programs, reforming immigration and 
refugee laws, and introducing stricter penalties for migration infringements. For example, recent legislative changes introduced by the Canadian government give greater discretionary powers to the immigration minister and officers to select, limit, or fasttrack new immigration and refugee applications for those they deem desirable, and accordingly to refuse or conditionally authorize migrants to Canada. In 2009 alone, the Harper government imposed new visa requirements, lifted a moratorium on removal, and carried out workplace raids. Conservatives also defended policies justifying rendition to torture and security certificates. Temporary migrant worker programs have been extended from agriculture to construction and tourism. As a result, Canada has admitted more temporary foreign workers than permanent residents since 2006 (Citizenship and Immigration Canada, 2011). These measures and trends result in diverting particular types of migrants away from the permanent status authorized by immigration law into temporary, precarious, and disposable working conditions. In 2008, the year preceding the imposition of the visa requirement for Mexican travelers and that of the highest number of Mexican refugee claimants, the number of temporary workers from Mexico in Canada was seven times higher than that of Mexican permanent residents. ${ }^{4}$ Although the figures vary slightly over time, the patterns clearly remain the same: immigration policy has shifted toward temporary-migrant-worker programs and Mexico represents a large labor pool for them. Mexicans in Canada are preferred as temporary workers rather than as permanent citizens. Indeed, temporary-migrant-worker programs have been favored to mitigate the adverse effects of structural programs that federal and state domestic policies have failed to resolve both in Canada and Mexico (Hernández Velázquez, Leco Tomás, and Aguilar Armendáriz, 2011).

Canada's recent imposition of visas as a response to the arrival of Mexican refugee claimants is an integral part of a neoliberal discourse of control and security because it acts to extend the discourse of criminality to refugee claimants, that is, to those who have submitted an asylum claim and even to those who have no intention of filing a claim because they now belong to a targeted national group. With the increasing trend of the governance of mobility being seen as a matter of national security, marginalized migrants and refugees are targeted similarly even though their respective modalities of mobility and exclusion are different. Targeted by punitive policy and populist antiimmigration rhetoric, undocumented migrants have a tenuous status stemming from their illicit mode of entry and their construction as criminals, leaving them especially vulnerable to precarious working conditions. Vulnerability and the need to evade au-

\footnotetext{
${ }^{4}$ In 2005, there were 12941 foreign temporary workers from Mexico, compared to 2853 permanent residents. Refugee claims from Mexico for the same year totaled 3 346. Numbers for 2008 and 2011 were 20995 and 18655 temporary workers, respectively, compared to 2831 and 3643 permanent residents and 9527 and 677 refugee claimants (Citizenship and Immigration Canada, 2012).
} 
thorities hover over undocumented migrants' everyday lives. For refugee or asylum claimants, vulnerability is played out right at their arrival in their demand for protection and their obligation to prove they would be persecuted if they returned home. However, in the nexus of criminality/ security given priority by many governments, the presumption of abuse prevails until proof of persecution is officially sanctioned (Pratt, 2005; Dauvergne, 2008; Mountz, 2010). In a North American context where Mexican migrants are broadly viewed as "illegal" economic migrants, this reputation now inevitably extends to their status as refugee claimants because they are suspected of disguising economic motivations and circumventing immigration procedures and controls.

\section{Refugees at Risk or "Risky" Refugees}

In 1969, Canada accepted the 1951 un Refugee Convention and its 1967 Protocol, and therefore agreed to offer refugee protection. Over the years, Canada has acquired an international reputation for welcoming refugees to its overseas sponsorship program selecting mainly from refugee camps. However, the inland process for individuals making a claim at a port-of-entry or at Citizenship and Immigration Canada offices has been more contentious because of structural inefficiencies. The refugee system's delays and inefficiencies have caused a massive backlog and triggered the need for legislative reform. The backlog has created a window of opportunity for the growing industry of immigration/ refugee consultants promising a way into Canada's system.

When talking to the Mexican president in Guadalajara in August 2009, Harper made it very clear that the visa requirement had nothing to do with the Mexican government, but instead rested with problematic Canadian legislation. Harper and Kenney have both used this kind of doublespeak when talking about the refugee system, switching from blaming the mala fides who damage the prospects of the bona fides to blaming the broken Canadian refugee-determination system rendered inefficient by legislation intended to deter entry. The opportunity created by the backlog seems to disguise the Conservatives' contempt for the refugee law's consistency with the 1982 Canadian Charter of Rights and Freedoms and the subsequent 1985 Singh v. Ministry of Employment and Immigration landmark Supreme Court decision. Based on the Charter's Section 7, the Singh ruling held that foreign nationals on Canadian soil are protected by the provisions of the Charter, even if costs and delays required in providing a hearing to claimants and guaranteeing the provisions of the Charter are deemed administratively inefficient by governmental agencies (Kelley and Trebilock, 1998). The Singh decision led to the creation of the Immigration and Refugee Board 20 years ago, and entitles refugee claimants to an oral hearing in accordance with the principles of 
fundamental justice and international law. In other words, the Singh decision ensures the right of refugee claimants to liberty and security of their persons during the determination process of their claims by the Immigration and Refugee Board. Conservative politicians, especially those with roots in the defunct extreme-right Reform Party and its successor, the Canadian Alliance, have consistently and openly expressed their dislike of the 1985 decision (Köhler, 2009). For them, the extension of the protection of Charter of Rights and Freedoms to refugee claimants results in excessive provisions, expenditures, and delays.

Even before being appointed minister of citizenship, immigration, and multiculturalism in 2006, Kenney had long condemned inland claims as "bogus" refugee claims. From United States war resisters to Mexican refugee claimants, Kenney publicly accused alleged "bogus" refugee claimants of threatening the integrity of the refugee (and welfare) system in Canada and to be the reason for the chronic administrative backlog (CBC News, 2009). ${ }^{5}$ In a letter to the daily National Post shortly after the events of September 2001 in the U.S., Kenney argued for the "overriding of the Singh decision" and the "detention of all undocumented arrivals until their identity is verified" (quoted in Köhler, 2009). Even then, Kenney defended the need for a refugee system that assists "legitimate" refugees "rather than lawbreakers and queue-jumpers" (quoted in Köhler, 2009). Kenney claimed that he "cannot tolerate a situation where they see people getting a plane ticket, arriving here, saying the magic word 'refugee,' getting quasilanded status, getting a work permit and/or welfare benefits. That is an insult to the millions of people who aspire to come to Canada legally" (quoted in Köhler, 2009).

In the 2009 press release announcing the new visa requirements for Mexico, Kenney argued that recent refugee claims from Mexico represented an objectionable 25 percent of all claims received. ${ }^{6}$ Insisting on the dichotomy between "false" and "real" refugees, Kenney insisted that "in addition to creating significant delays and spiraling new costs in our refugee program, the sheer volume of these [Mexican] claims is undermining our ability to help people fleeing real persecution" (quoted in Citizenship and Immigration Canada, 2009a). Emphasizing the low 11-percent acceptance rate of Mexican refugee claims (compared to an overall rate of 45 percent) by the Immigration and Refugee Board, Kenney unambiguously claimed that "the visa process will allow

\footnotetext{
${ }^{5}$ Over the years, the Immigration and Refugee Board has often accumulated backlogs, but none as longlasting as the estimated 60000 to 65000 pending claims restraining the refugee determination process in 2009. The problem resides not solely at the entrance of the system, but rather in the middle and end of it because the Conservative government failed to fill vacancies on the board over time (Office of the Auditor General of Canada, 2009).

${ }^{6}$ From 2005 to 2009, Mexico was the leading country from which claims were submitted, but the number of Mexican claimants had been steadily rising since the late 1990s. With the visa requirement, claims from Mexico have dropped as expected, decreasing to 7607 in 2009 and 1221 in 2010 (Citizenship and Immigration Canada, 2011).
} 
us to assess who is coming to Canada as a legitimate visitor and who might be trying to use the refugee system to jump the immigration queue" (quoted in Citizenship and Immigration Canada, 2009a). On many occasions, Harper echoed Kenney's claim that the 89-percent refusal rate of claims made by Mexicans "suggest[s] wide scale and almost systematic abuse," thus exhibiting and promoting a culture of suspicion, disbelief, and distrust (Kenney quoted in Collins, 2009a).

Zimmerman (2011: 336) observes that "the state's processes of granting or refusing asylum are central to how meaning is assigned," and "abusive applicants are often framed as being social or economic migrants" and therefore as criminals. The problem of "bogus" or "false" claims and the perception that refugee claimants are economic migrants in disguise rather than "real" refugees fleeing persecution (a dichotomy also described as fraudulent and genuine, deserving and undeserving, desirable and undesirable) is based on political and other forms of violence and does not recognize socio-economic issues. These categorizations are based on a moralistic discourse that considers both the conduct and motivation of refugee claimants wrong and suspect. This discourse operates on the assumption that genuinely deserving refugees are languishing in camps overseas and therefore claimants who actually arrive in Canada are less in need of protection and consequently less likely to be "genuine" refugees (Pratt, 2005). Adding to this problematic assumption of un/deserving claimants is the neoliberal credo that values the entrepreneurial ethos and stigmatizes the person in need as immediately suspected of not contributing or abusing the state's largesse. Mexican refugee claimants in Canada, as explicitly stated by Conservative politicians, were widely assumed to be fraudulently trying to take unfair advantage of the system. As Pratt demonstrates (2005: 216), "The emergence and conflation of the problems of the 'bogus refugee' and the 'welfare cheat' and the way in which these linked threats [are] framed by the crime-security nexus and the specter of fraud ... produced a powerful, new, hybrid threat -the fraudulent criminal refugee." The deserving refugee "at risk" then becomes widely recast as the "risky" refugee (Pratt, 2005: 18). In the case of Mexican refugee claimants, the visa requirement served first and foremost as a deterrence and risk management technology, where risk is constituted by moral considerations shaping the deserving and undeserving.

In maintaining a sharp distinction between "false" and "real" refugee claimants in their public addresses, Harper and Kenney have been seen as preempting decisions of the Immigration and Refugee Board, the independent administrative tribunal solely responsible for determining the admissibility of refugee claims in Canada, by concluding that the majority of Mexican claimants are "bogus refugee claimants" by insisting that "real" refugees are overseas (Collins, 2009a). While, as minister, Kenney has discretionary powers to admit claimants on particular humanitarian grounds, 
his explicit position on alleged "bogus" claimants has been increasingly perceived as political interference in due process (already significantly discretionary) by creating systematic discrimination and prejudice against a targeted group of claimants. Political discourses legitimize a win-win situation for both visa enforcement and legislative reform. The minister's discretionary power to unilaterally develop a list of designated safe countries of origin (or parts of countries or groups) for the purpose of expedited processing was first legislated in the 2010 Balanced Refugee Reform Act and reasserted in the 2012 Protecting Canada's Immigration System Act (Parliament of Canada, 2010; 2011). ${ }^{7}$

While imposing a visa on a particular country is within the power of the Canadian government, linking the visa requirement to the need to curtail so-called "bogus" refugee claims from a specific national group is misguided because international refugee law stipulates that each claim must be examined individually. Questioning the legitimacy of refugee claimants and deterring claims have been ways to impair and erode refugee applicants' human rights by reasserting border control. Many expert organizations, such as Amnesty International (2009), the Canadian Council for Refugees (2009b), and the Refugee Lawyers' Association of Ontario (quoted in Collins, $2009 b$ ) agree that it is inappropriate for politicians to comment on who is or is not a legitimate refugee and conclude that an individual does not have a well-founded fear of persecution based only on his/her national origin. Commenting on the numerous verbal dérapages of Minister Jason Kenney, former Immigration and Refugee Board chairman Peter Showler said he was "not . . . aware of a single previous minister of immigration who has made such remarks, who has intruded on the judicial process in this way" (quoted in Collins, 2009b). Such comments were echoed by the Refugee Lawyer's Association of Toronto, which contends that "Canadian public should be shocked that a minister would interfere in the work of an independent body" (quoted in Collins, 2009b). Such prejudicial bias is seen as particularly problematic given that, under the recent refugee law changes, the minister will have full discretion over determining Canada's list of designated countries of origin or the so-called list of "safe countries," i.e., "countries that do not normally produce refugees" (Citizenship and Immigration Canada, 2012).

\footnotetext{
7 This act sponsored by Jason Kenney and approved by Parliament in June 2012, is also known as Bill C-31-An Act to Amend the Immigration and Refugee Protection Act, the Balanced Refugee Reform Act, the Marine Transportation Security Act and the Department of Citizenship and Immigration Act (Parliament of Canada, 2010; 2011). Under this new legislation, the minister has the power to choose which countries are safe, and claimants from a safe country will no longer be able to appeal the Immigration and Refugee Board decision. Safe country claimants will have to wait a year before applying for compassionate and humanitarian considerations and will be able to ask for a judicial review by the federal court, but could be deported at any time during this process.
} 


\section{Mexico, a "Safe Country"?}

Since 2006, when the newly elected administration of Felipe Calderón launched military operations against the country's drug cartels, more than 50000 military personnel have been deployed on the streets, mostly in the states of Baja California, Chihuahua, Nuevo León, Veracruz, and Tamaulipas (Estévez, 2012a). ${ }^{8}$ Military assaults have focused on the capture and killing of drug cartel leaders, leaving cartels to compete in the strategic restructuring of relations and territories. As a result of the intensity of the violence, citizens have been caught in "shootings, crossfire, beheadings and car bombings directed at the authorities, as well as kidnappings and executions" (Estévez, 2012a: 22). An estimated 50000 to 60000 Mexicans have died since 2006, 16000 persons are said to be missing, and 230000 others have left their homes (Estévez, 2012a: 24; Luthnow, 2012). Mexican authorities have claimed that the drug war has been limited to certain states and cities where criminals are killing each other. However, others have argued that it has unleashed an unprecedented wave of violence and insecurity throughout the whole country (Wright, 2012; Estévez, 2012a). As Wright remarks (2012), while the brutality of the narco-violence and conflicts created by both criminal activities and military harassment might be concentrated in certain areas, it is nevertheless part of the consciousness of all Mexicans (inside and outside Mexico).

The drug war has led to a serious human rights crisis. According to Amnesty International's 2012 annual report, drug cartels and other criminal gangs, sometimes acting in collusion with police and public officials, are responsible for human rights abuses including kidnapping, rape, and murder. Migrants, journalists, women, and defenders of human rights have been the victims of killings or numerous threats that have never been investigated (Estévez, 2012a; Wright, 2012; Amnesty International, 2012). Such human rights violations, along with others such as intimidation, torture, forced disappearances, extrajudicial killings, and the use of excessive force are widely reported, but the large majority of these abuses go unpunished. In fact, the Mexican government considers such violations "exceptional" and remains without effective measures to prevent, investigate, or punish serious human rights violations committed by criminal organizations and police forces (Estévez, 2012b; Amnesty International, 2012). It is in the absence of state protection that violence against citizens becomes a human rights violation. In that sense, García Clarck (2011: 13) argues the "human rights crisis in Mexico is a crisis of distrust of the Mexican state's capacity to safeguard its citizens' fundamental rights. A determining factor in this distrust is institutional

\footnotetext{
${ }^{8}$ Recognizing that drug "cartels pose a serious threat to the security of Mexico," Canada and the U.S. provided technical assistance to train federal police in Mexico in 2009 through an Anti-Crime Capacity Building Program (Prime Minister of Canada Stephen Harper, 2012).
} 
inefficacy, manifested particularly in a high-cost public security policy with negligible results, as well as the partisan bias and inconsistency in the administration of justice." The human rights crisis in Mexico has therefore been exacerbated by a high level of impunity, and, as Estévez (2012a: 23) argues, “Impunity in Mexico is not simply the result of incompetence or the inability to investigate, but the consequence of the high levels of corruption and the penetration of the criminal justice system and the police forces." In its incapacity to protect its citizens, the state becomes involved in perpetuating these human rights violations.

The nature of narco-violence and impunity in human rights violations pose a particular challenge to the dominant understanding of asylum seekers or refugee claimants as persons suffering persecution and being unable to secure any form of protection. By insisting that human rights violations are exceptional or letting them go unanswered (due to a lack of judicial investigation) and affirming that the violence generated by the drug war is concentrated in certain areas (and therefore persons displaced by violence can actually relocate to another area), the Mexican state has constructed citizens needing and seeking protection outside of the conventional definition of the "asylum seeker." The government's discourse of drug violence therefore normalizes "a blame-the-victim story," where drug violence is presented as strictly internal to the drug trade, i.e., perpetrated by criminals against criminals and therefore not affecting law-abiding citizens (Wright, 2012). As Wright explains,

A key component of this discourse is that the murderers target people for specific reasons; the violence is not random. Since these reasons are internal to the drug trade, the general public cannot know them, but as the violence reflects the killing of criminals by criminals, the general public, which is largely innocent of criminal activity, need not worry. (2012: 572)

Still, between 2006 and 2010, 44019 Mexicans sought protection and asylum in other countries, 13700 of them in the United States and 30142 in Canada (Estévez, 2012a: 29). The majority of these asylum applications are being systematically rejected in the United States and Canada on the basis that victims of drug wars are not seen as "refugees" and on the premise that the Mexican state is able to protect its citizens. Such claims about the Mexican government's ability to control rather than normalize and depoliticize the ongoing narco-violence are increasingly contested. According to García Clarck, "To climb out of this crisis, constitutional and legal reforms are needed, as are more effective public policies and, of course, a real commitment by the authorities to the defense and promotion of human rights" (2011: 13). In the meantime, Mexicans have increasingly sought asylum in other countries, notably in Spain, Sweden, France, the United Kingdom, Luxembourg, and Norway. The rise in the 
number of applications to European countries is motivated by the fear of violence and persecution (Estévez, 2012a: 30).

\section{Conclusion}

On the day following the imposition of the visa requirements for Mexicans, an article in the Toronto daily newspaper Globe and Mail reported that Kenney was planning an overhaul of Canada's refugee system using the United Kingdom system as a model (Clark, 2009). That model screens claimants according to their national origins (rather than individual circumstances) in order to reject or fast-track their refugee status. Only refugees from conflict zones and totalitarian regimes would then be able to claim asylum, thus drastically reducing access to the refugee system. Based on this position, it is not surprising that Canadian authorities feel they can legitimately preempt the cases of Mexican refugee claimants as "fraudulent." While the minister claims that the new refugee reforms would not limit access to refugee applicants from "safe countries," rhetorical distortions have already criminalized Mexicans as "abusers" of the Canadian refugee system. Through this construct of alleged abuse, politicians have reduced a complex migration condition to "bogus" claims, trivialized refugee and human rights, and failed to appreciate Mexico's complex political reality.

The minister will have full power to compile the list of so-called "safe countries," i.e., "countries that do not normally produce refugees, that have a robust human rights record, and offer strong state protection" (Citizenship and Immigration Canada, 2010). The problem with the ministerial power to pre-determine claims from allegedly "safe" countries is that this kind of approach challenges international law, which requires individual assessment of protection needs. The compilation of such a list is also fraught with potential for conflict in international relations, sensationalist media reporting, misinformation, and the misrepresentation of complex issues, as well as the politicization of screening approaches, particularly in an amplified context of national security. As Dauvergne (2008) reminds us, refugee law should not be about protecting sovereignty, but rather the human rights of those needing protection. Troubled by the number of refugee applications, Canadian politicians seem to overlook the fact that while 55 percent of all the refugee claimants in Canada are said not to require protection, 45 percent do. If one values human rights, even the 11 percent in 2009 and the 17 percent in 2011 of Mexican claimants needing protection should not be disregarded.

In designating Mexico as a "safe country," Canada would eliminate the need for the visa, but only by denying the human rights crisis created by the violent drug wars 
and the erosion of the power of the state to protect and to govern (Estévez, 2012a; Wright, 2012). Whether Mexico will end up on Minister Kenney's list of "safe countries" or not remains to be seen. It is, however, unlikely that Canada will designate Mexico as "unsafe" given its existing trade and investment ties and bilateral relationships. There rests the paradoxical perceptions of Mexico by Canada as being or not being a respected economic partner and political friend, depending on the political rationalities needed -yet exclusion remains the goal.

\section{BIBLIOGRAPHY}

\section{AMnESTY INTERNATIONAL}

2012 "Informe anual 2012: El estado de los derechos humanos en el mundo. México," http: / / www.amnesty.org/es / region/mexico/ report-2012.

2009 "Letter to the Honourable Jason Kenney," http: / / www.amnesty.ca / resource _centre / news / view.php?load=arcview\&article $=4855 \& c=$ Resource + Centre + News.

\section{ANONYMOUS}

2009 Personal communication with the author, Mexico City, October.

BACON, DAVID

2008 Illegal People: How Globalization Creates Migration and Criminalizes Immigrants, Boston, Beacon Press.

BIGO, DiDIER

2002 "Security and Immigration: Toward a Critique of the Governmentality of Unease," Alternatives, vol. 27, no. 1, pp. 63-92.

\section{CAMPION-SMith, BRUCE}

2010 "Ottawa's Visa Rule Is Costing Canada Visitors, Mexican President Says," The Toronto Star, May 27, http:/ / www.thestar.com/news/canada/article/ 815228--ottawa-s-visa-rule-is-costing-canada-visitors-mexican-president -says.

Canada Visa Application Centre

2011 "Required Documents," http:/ / cicmex.com.mex/en-Mx/selfservice/CAN _required_documents. 


\section{Canadian Council for Refugees}

2009a "Lives in the Balance: Understanding Current Challenges to the Refugee Claim Process," June, http: / / www.ccrweb.ca/ documents/ refugeeclaimsFAQ.pdf.

$2009 b$ "The Challenge of Fair and Effective Refugee Determination," July 23, http:/ / www.ccrweb. ca / documents / fairdeterminationsummary.pdf.

CARENS, Joseph H.

2010 Immigrants and the Right to Stay, Cambridge, MIT Press.

CBC News

2009 "Kenney's Comments Prejudice Hearing for War Resisters, Critic Says," CBC News, January 9, http:/ / www.cbc.ca/canada/story/2009/01/09/refugee -war.html.

\section{Citizenship And Immigration CANADA}

2012 "Facts and Figures 2011: Immigration Overview-Permanent and Temporary Residents," http:/ / www.cic.gc.ca/english/pdf/research-stats/ facts2011.pdf.

2011 "Facts and Figures 2010: Immigration Overview-Permanent and Temporary Residents," http:/ / www.cic.gc.ca/english/pdf/ research-stats/facts2010.pdf.

2010 "Balanced Refugee Reform," http://www.cic.gc.ca/english/refugees/ reform.asp.

2009a “Canada Imposes a Visa on Mexico," press release, July 13, http: / / www.cic .gc.ca/english / DEPARTMENT / MEDIA/ releases/2009/2009-07-13.asp.

2009b “Application for Temporary Resident Visa (TRV)," http:/ / www.cic.gc.ca/ english/information/applications/visa.asp.

\section{Clark, Campbell}

2009 "Minister Calls for Overhaul of Canada's Refugee System," The Globe and Mail, July 15, http://www.theglobeandmail.com/news/national/minister-calls -for-overhaul-of-canadas-refugee-system/article1218679/.

\section{Collins, Michelle}

2009a "Cabinet Pulls the Plug on Mexican and Czech Visa-free Travel," Embassy, July 15, http: / / www.embassymag.ca/page/view/adios_canada-7-15-2009.

2009b "Political Interference Crippling Refugee Board: Former Chair," Embassy, July 22, http:/ / www.embassymag.ca/page/view/political_interference-7 -22-2009. 
DAuvergne, CATHERINE

2008 Making People Illegal: What Globalization Means for Migration and Law, New York, Cambridge University Press.

DAVIS, JEFF

2009a "Relations with Mexico at 'Lowest Ever' Level: Experts," Embassy, August 5, http:/ / www.embassymag.ca/page/view/mexico_relations-8-5-2009.

2009b “un Refugee Agency Cries Foul on Mexican, Czech Visas," Embassy, September 19, http:/ / www.embassymag.ca/page/view/un_refugee_agency-8-19-2009.

De Genova, Nicholas

2004 "The Legal Production of Mexican/Migrant 'Illegality'," Latino Studies, vol. 2, pp. 160-85.

\section{EstéveZ, ARIADNA}

2012a "La violencia en México como crisis de derechos humanos: las dinámicas violatorias de un conflicto inédito," Contemporánea, vol. 2, no. 1, pp. 21-44.

2012b "Asilo y derechos humanos en Estados Unidos y Canadá. Cuestionamientos a Giorgio Agamben," Norteamérica, year 7, no. 1, pp. 183-205.

García Clarck, Rubén R.

2011 "Human Rights Crisis in Mexico," Voices of Mexico, no. 89, Winter, pp. 10-13.

GOUVERNEMENT DU QuÉBEC

2009 “Monsieur Jason Kenney," letter, July 24, http:/ / www.mri.gouv.qc.ca/ PDF/ actualites / lettre_visas_jason-kenney.pdf.

\section{Government of CANADA}

1982 “Canadian Charter of Rights and Freedoms," http:/ / www.efc.ca/pages/ law / charter/ charter. text.html.

HERNÁNDEZ, JAIME J.

2009 “SRE no pedirá visas a turistas de Canadá," El Universal, July 17, http:/ / www.eluniversal.com.mx/nacion/169766.html.

Hernández Velázquez, Jorge A., Casimiro Leco Tomás, and Liliana Aguilar Armendáriz

2011 "México y Canadá: complementariedades desatendidas en materia migratoria," Escenarios XXI, vol. 1, no. 7, pp. 48-64. 
Hervieux-Payette, Céline

2009 “My Dear Mexican Friends," letter, July 17, http:/ / www.eurekablog.ca/wp -content/ uploads/2009/07/en_carta-para-mexico.pdf.

ImMigration AND Refugee BoARd of CANADA

2011 "Report on Plans and Priorities. 2011-2012 Estimates," Treasury Board of Canada, http: / / www.tbs-sct.gc.ca / rpp/2011-2012/index-eng.asp.

2006 "Immigration and Refugee Board of Canada: An Overview," http:/ / www .irb.gc.ca/Eng/brdcom/ publications / oveape / Documents / overview_e. pdf.

KANSTROOM, DANIEL

2004 "Criminalizing the Undocumented: Ironic Boundaries of the post-September $11^{\text {th }}$ 'Pale of Law'," North Carolina Journal of International Law and Commercial Regulation, vol. 29, pp. 639-70.

Kelley, Ninette, and Michael J. Trebilock

1998 The Making of the Mosaic: A History of Canadian Immigration Policy, Toronto, University of Toronto Press.

KÖHLER, NiCHOLAS

2009 "A Crackdown on Queue-Jumpers," Maclean's, July 28, http: / / www2 .macleans.ca/2009/07/28/a-crackdown-on-queue-jumpers/.

LATHAM, ROBERT

2009 "Reframing Mobile Subjectivity and Border Security in North America," paper presented at Border Governance: A Comparative North American Study Conference, Mexico City, October 5-7.

Latin America Data BASE

2009 "Canada Implements Visa Requirement for All Mexican Visitors," SourceMex, July 22, http:/ / www.allbusiness.com/government/government-bodies -offices / 12579968-1.html.

LuTHNOW, DAVID

2012 "Mexico Drug Violence Shows Decline," The Wall Street Journal, June 12, http:/ / online.wsj.com. 
MARTínEZ, MARIO

2009 "Justifica Canadá la visa por el exceso de falsos refugiados mexicanos," La Prensa, August 10, http:/ / www.oem.com.mx/laprensa/notas/n1279988.htm.

Massey, Douglas, Jorge Durand, and Nolan J. Malone

2002 Beyond Smoke and Mirrors: Mexican Immigration in an Era of Economic Integration, Thousand Oaks, California, Sage.

MAYEDA, ANDREW

2009 "Harper Blames Canada's Refugee System for Mexican Visa Uproar," National Post, August 10, http: / / www.nationalpost.com/news/ story.html?id=1877551.

MounTz, Alison

2010 Seeking Asylum: Human Smuggling and Bureaucracy at the Border, Minneapolis, University of Minnesota Press.

NAFTA SECRETARIAT

1993 “Legal Texts/North American Free Trade Agreement/Preamble," http:/ / www.nafta-sec-alena.org/.

NEWTON, LiNA

2008 Illegal, Alien or Immigrant: The Politics of Immigration Reform, New York, New York University Press.

Office of the Auditor General of Canada

2009 "Status Report of the Auditor General of Canada to the House of Commons," Ottawa, Ministry of Public Works and Government Services Canada, http: / / www.oag-bvg.gc.ca/internet/docs / parl_oag_200903_02_e.pdf.

O’Neil, Peter, and Meagan FitzPatrick

2009 "Canada to Require Visas from Mexico, Czech Republic," Canada.com. July 13, http:/ / www2.canada.com/topics/ news / story.html?id=1786831.

PARLIAMENT OF CANADA

2011 "Bill C-31 Protecting Canada's Immigration System Act," http:/ / www.parl.gc.ca/ House Publications $/$ Publication.aspx?Language=E\&Mode=1\&DocId=5391960\&File=27\# .

2010 "Bill C-11 Balanced Refugee Reform Act" (assented to 29 June 2010), http: / / www .parl. gc.ca/HousePublications $/$ Publication. aspx?Docid $=4644728 \&$ file $=4$. 
PRATT, ANNA

2005 Securing Borders: Detention and Deportation in Canada, Vancouver, University of British Columbia Press.

Prime Minister of Canada Stephen Harper

2012 “Canada Provides Basic Training for Federal Recruits," August 9, http:// pm.gc.ca.

Ramírez Meda, Kenia María, and Pablo Nicolás Biderbost Moyano

2011 "Acción y reacción: Los motivos de la modificación política migratoria canadiense y la respuesta de la clase política mexicana," Revista Mexicana de Estudios Canadienses, vol. 21, pp. 23-34.

ROSS, OAKLAND

2010 "Restriction a Blot on Canada's Image for Mexican Visitors," Toronto Star, May 28, p. A14.

SIMPSON, JEFFREY

2010 "Relations are Frosty, But It's Not Quite Adios Amigo," The Globe and Mail, November 13, p. F9.

Singh $v$. Minister of Employment And IMmigration

1985 1 S.C.R. 177, http: / / csc.lexum.umontreal.ca/ en/1985/1985rcs1-177/ 1985rcs1 $-177 . h t m l$.

Studer Noguez, IsABel

2009 "Canadá-México: adiós a la 'relación estratégica'” (I), Offnewws.info, July 4, http: / / www.offnews.info/ verArticulo.php?contenidoID=15900.

United NATIONS

2009 "International Migrant Stock: The 2008 Revision UN Population Division," http:/ / www.un.org/migration?index.asp?panel=1.

United Nations High Commissioner for Refugees

1951 "Convention and Protocol Related to the Status of Refugees," http:/ / www .unhcr.org/ protect/PROTECTION/3b66c2aa10.pdf. 
United States Department of State

2012 "Visitor Visas-Business and Pleasure," http: / / travel.state.gov /.

VALPY, MiCHAEL

2009 "Visa Controls on Mexico 'Humiliating,' Senator Says," The Globe and Mail, October 24, p. A13.

WhitTINGTON, LES

2009 "No Plans Yet to Lift Mexico Visa Requirement: Harper," The Toronto Star, August 9, http: / / www.thestar.com/news / canada/article/678661.

Wright, Melissa W.

2012 “Wars of Interpretations," Antipode, vol. 44, no. 3, pp. 564-580.

ZiMMERMAN, SUSAN E.

2011 "Reconsidering the Problem of 'Bogus' Refugees with 'Socio-economic Motivations' for Seeking Asylum," Mobilities, vol. 6, no. 3, pp. 335-352. 
